\title{
Pemanfaatan Oleoresin Jahe (Zingiber officinale) untuk Mengatasi Kelainan Antioksidan Intrasel Superoxide Dismutase (SOD) Hati Tikus Di Bawah Kondisi Stres
}

\author{
The Utilization of Ginger (Zingiber officinale) Oleoresin to Recover Impairment of \\ Intracelluler Antioxidant Superoxide Dismutase (SOD) On the Liver of Rats Under \\ Stress Condition
}

\author{
Tutik Wresdiyati ${ }^{1 *}$, Made Astawan ${ }^{2}$, I Ketut Mudite Adnyane ${ }^{1}$, dan Renny Candra \\ Prasetyawati $^{2}$
}

${ }^{1}$ Laboratorium Histologi, Departemen Anatomi, Fakultas Kedokteran Hewan *Penulis untuk korespondensi ${ }^{2}$ Departemen Teknologi Pangan dan Gizi, Fakultas Teknologi Pertanian-Institut Pertanian Bogor. Kampus IPB Darmaga Bogor 16680.

\begin{abstract}
This study was conducted to evaluate the activity of ginger oleoresin (Zingiber officinale) on the intracelluler antioxidant-superoxide dismutase (SOD) in the liver of rats under stress condition. A total of twuenty five Wistar rats were used for this study. They were divided into five groups ; (1)K (control), (2) $\mathrm{S}$ (stress), (3) $\mathrm{O}+\mathrm{S}$ (oleoresin followed by stress), (4) $\mathrm{S}+\mathrm{O}$ (stress followed by oleoresin and (5) $\mathrm{O}+\mathrm{S}+\mathrm{O}$ (oleoresin followed by stress then oleoresin). The dose of oleoresin is $60 \mathrm{mg} / \mathrm{Kg} / \mathrm{BW} / \mathrm{day}$ for seven days. Stress condition was done by five days fasting and smimming for five minutes/day, while drinking water was provided ad libitum to all groups. The results showed that ginger oleoresin significantly decreased malonaldehyde (MDA) and elevated SOD activity. The immunohistochemical evaluation also showed that ginger oleoresin increased the content of copper,zinc-superoxide dismutase (Cu,Zn-SOD) in the liver of rats under stress condition. These effects were showed in the tissues of rats treated by ginger oleoresin before or after stress or combination of both.
\end{abstract}

Key words: Superoxide dismutase (SOD), stress, ginger, liver, rat

Diterima: 19 Mei 2004, disetujui: 06 Juli 2004

\section{Pendahuluan}

Antioksidan, free radical scavenger, berperan dalam melindungi sel terhadap gangguan oksidan dan secara tidak langsung memelihara keseimbangan oksigen yang toksik (Touati, 1992). Peranan tersebut dapat dilakukan dengan mengurangi, menahan dan mencegah proses oksidasi (Schuler, 1990), serta katalisasi radikal bebas oleh enzim antioksidan intrasel (Mates et al., 1999). Enzim antioksidan yang terdapat di dalam sel meliputi catalase, glutathione peroksidase, dan superoxide dismutase (SOD) (Asayama et al., 1996); copper zinc-superoxide dismutase
(Cu,Zn-SOD) (Fridovich, 1975) dan manganese superoxide dismutase (Mn-SOD) (Marklund, 1984).

$\mathrm{Cu}, \mathrm{Zn}$-SOD merupakan salah satu antioksidan endogen yang berperan penting dalam mengkatalisis radikal bebas anion superoxide menjadi hidrogen peroksida dan molekul oksigen (Mates et al., 1999). Dengan kemajuan teknik imunositokimia, sel-sel penghasil SOD telah berhasil dideteksi pada jaringan tikus (Dobashi et al., 1989; Wresdiyati and Makita, 1997). Profil SOD juga telah dilaporkan pada kondisi patologis seperti stress dan diabetes mellitus (Wresdiyati 1999; Wresdiyati et al., 2002; Wresdiyati et al., 2003; 
Wresdiyati, 2003a), serta pada jaringan neoplastik (Keller et al., 1991).

Penelitian sebelumnya menunjukkan bahwa kondisi stres mengakibatkan terjadinya kelainan morfologi dan peningkatan jumlah organel peroksisomes pada ginjal kera Jepang (Wresdiyati and Makita, 1995). Kondisi stres juga menimbulkan inflamasi dan penurunan kandungan antioksidan $\mathrm{Cu}, \mathrm{Zn}$-SOD pada hati dan ginjal tikus (Wresdiyati, 1999; Wresdiyati et al., 2002, Wresdiyati, 2003a).

Oleoresin jahe telah dilaporkan memiliki potensi antiinflamasi pada jaringan hati dan ginjal tikus di bawah kondisi stres (Wresdiyati et al., 2003; Wresdiyati 2003b). Kikuzaki and Nakatani (1993) melaporkan secara in vitro bahwa oleoresin jahe mempunyai daya antioksidatif lebih tinggi dari $\alpha$-tokoferol. Namun demikian, belum pernah dilaporkan aktivitas antioksidan oleoresin jahe dalam mengatasi kelainan antioksidan intrasel-SOD in vivo pada jaringan hati tikus, terutama pada kondisi stres.

Penelitian ini bertujuan untuk mempelajari peranan kandungan senyawa antioksidan oleoresin jahe dalam mengatasi penurunan antioksidan intrasel-SOD pada hati tikus akibat perlakuan stres. Penelitian ini merupakan salah satu upaya pemanfaatan jahe dalam mengatasi kelainan antioksidan intraselSOD pada jaringan tubuh, terutama yang diakibatkan oleh kondisi stres. Sehingga oleoresin jahe diharapkan dapat dipakai sebagai bahan alternatif pencegahan maupun pengobatan terhadap kerusakan dini sel atau organ tubuh akibat rendahnya status SOD akibat stres.

\section{Metode Penelitian}

\section{Ekstraksi oleoresin jahe}

Penelitian ini menggunakan rimpang jahe emprit (kecil) yang berumur 10 bulan. Sebanyak 250 gram bubuk jahe diekstrak empat kali dengan menggunakan dua jenis pelarut organik $(500 \mathrm{ml})$ yang berbeda, methanol dan ethanol. Ekstrak yang diperoleh disaring kemudian disuling dengan rotaryvacum-evaporator.

\section{Analisis total fenol oleoresin jahe}

Analisis kadar total fenol juga dilakukan terhadap ekstrak jahe baik dengan pelarut metanol maupun etanol (AOAC, 1984). Pembacaan absorbansi dilakukan pada panjang gelombang $760 \mathrm{~nm}$.

\section{Analisis aktivitas antioksidan oleoresin jahe}

Analisis aktivitas antioksidan dilakukan menurut Chen et al., (1996). Pengukuran absorbansi dengan spektrofotometer pada panjang gelombang $500 \mathrm{~nm}$. Nilai pengukuran dinyatakan sebagai bilangan peroksida.

\section{Karakterisasi oleoresin jahe}

Lempeng GF-254 yang telah diaktifkan dengan pemanasan pada suhu $110^{\circ} \mathrm{C}$ selama empat jam diberi spot ekstrak yang berisi senyawa oleoresin dimulai pada garis batas lalu dimasukkan ke dalam wadah pengembang yang telah jenuh dengan eluen heksan dan dietileter dengan rasio $3: 7$, dan dibiarkan perambatan pelarut sampai batas akhir. Lempeng tersebut dikeluarkan dari wadah pengembangan dan terlihat fraksi-fraksi yang terpisah satu sama lainnya karena memiliki nilai Retardation Factor (Rf) yang berbeda.

\section{Perlakuan hewan dan pengambilan sampel jaringan hati tikus}

Tikus jantan galur Wistar sebanyak 25 ekor $(250 \pm 5 \mathrm{~g})$ dikelompokkan menjadi lima kelompok perlakuan yang terdiri dari lima ekor tikus untuk masing-masing kelompok (Tabel 1). Perlakuan stres dilakukan dengan cara puasa (tidak diberikan pakan), tapi diberi air minum ad libitum serta perenangan lima menit/hari selama lima hari. Pemberian oleoresin dengan dosis $60 \mathrm{mg} / \mathrm{Kg} / \mathrm{BB} / \mathrm{hari}$ dilakukan dengan sonde. Bersamaan dengan pemberian oleoresin, tikus juga diberikan pakan secara ad libitum. Penggunaan dosis oleoresin $60 \mathrm{mg} / \mathrm{Kg} / \mathrm{BB} /$ hari berdasarkan hasil penelitian sebelumnya yang menunjukkan dosis tersebut merupakan dosis oleoresin yang efektif sebagai antiinflamasi pada jaringan hati dan ginjal tikus akibat stres (Wresdiyati, 2003b; Wresdiyati et al., 2003). 
Sampel jaringan hati yang didapat dari setiap ekor tikus perlakuan kemudian dibagi dan kandungan $\mathrm{Cu}, \mathrm{Zn}-\mathrm{SOD} \quad$ secara tiga untuk analisis kadar MDA, aktivitas SOD, imunohistokimia.

Tabel 1. Kelompok perlakuan tikus percobaan dan jenis perlakuan yang diberikan

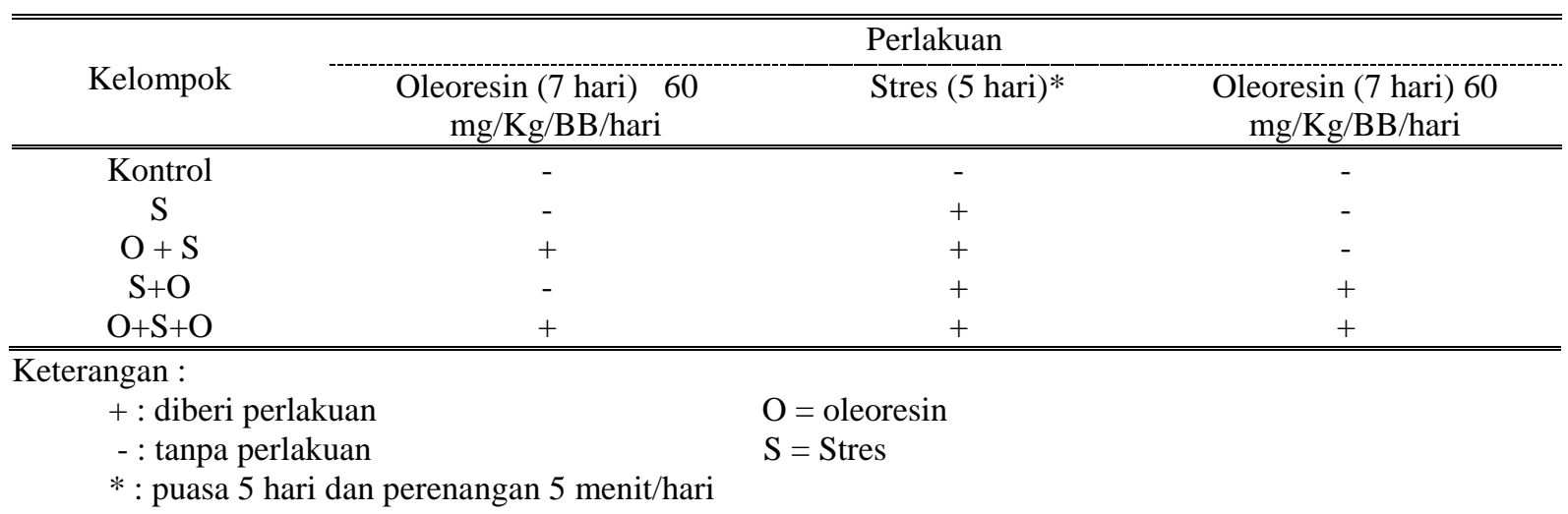

\section{Analisis kadar MDA}

Analisis kadar MDA dilakukan menurut Conti et al., 1991. Pengukuran kadar MDA menggunakan spektroflourometer pada panjang gelombang eksitasi $515 \mathrm{~nm}$ dan emisi $553 \mathrm{~nm}$. Kadar MDA sampel yang diperoleh dinyatakan dalam satuan $\mu$ mol per gram protein.

\section{Analisis aktivitas SOD hati tikus}

Sebanyak $\quad 400 \quad \mu l \quad$ larutan kloroform/etanol dingin 37,5/62.5 (v/v) ditambahkan ke dalam $150 \mu \mathrm{l}$ lisat hati. Kemudian divorteks selama 3 detik dan disentrifus pada kecepatan $4400 \mathrm{rpm}$ suhu $4^{\circ} \mathrm{C}$ selama 10 menit. Sebanyak 2,9 ml larutan A (campuran larutan xantin dan larutan sitokrom c) ditambah $50 \mu \mathrm{l}$ larutan baku (kontrol) atau sampel dan divorteks secara perlahan. Reaksi dimulai dengan menambahkan $50 \mu \mathrm{l}$ larutan $\mathrm{B}$ (xantin oksidase) dan divorteks secara perlahan. Pengamatan terhadap perubahan absorban yang terjadi dilakukan dengan spektrofotometer.

\section{Deteksi imunohistokimia terhadap Cu,Zn-SOD}

Jaringan hati difiksasi selama 24 jam dalam larutan Bouin, selanjutnya diproses dengan metode standar menggunakan parafin. Pewarnaan imunohistokimia pada preparat jaringan hati terhadap $\mathrm{Cu}, \mathrm{Zn}-\mathrm{SOD}$ menggunakan metode Dobashi et al. (1989) dengan modifikasi. Setelah dilakukan inaktivasi terhadap peroksidase endogen, kemudian potongan jaringan diinkubasi dalam antibodi monoklonal $\mathrm{Cu}, \mathrm{Zn}-\mathrm{SOD}$ (Sigma S2147) dilanjutkan dengan inkubasi dalam antibodi sekunder (Dako K1491). Produk reaksi antigen-antibodi divisualisasi dengan diamino benzidine (DAB).

Pengamatan terhadap sel-sel penghasil $\mathrm{Cu}, \mathrm{Zn}-\mathrm{SOD}$ dilakukan secara kualitatif terhadap produk reaksi positif pada sitoplasma dan inti sel hati dengan membandingkan intensitas warna cokelat yang terbentuk dan distribusinya pada seluruh bagian setiap preparat yang diamati.

\section{Analisis data}

Hasil pengukuran kadar MDA dan aktivitas SOD hati tikus perlakuan masingmasing dianalisis dengan Analisis Sidik Ragam menggunakan Rancangan Acak Lengkap (RAL). Untuk melihat perbedaan kadar MDA dan aktivitas SOD antar kelompok perlakuan dilakukan pengujian lanjut menggunakan uji beda Duncan. 


\section{Hasil dan Pembahasan}

\section{Kadar oleoresin dan total fenol ekstrak jahe}

Kadar oleoresin dan total fenol oleoresin rimpang jahe yang diekstrak dengan dua jenis pelarut dapat dilihat pada Tabel 2. Hasil analisis ragam menunjukkan bahwa jenis pelarut (metanol dan etanol) tidak berpengaruh nyata $(\mathrm{P}>0.05)$ terhadap kadar oleoresin ekstrak jahe.

Tabel 2. Kadar oleoresin dan total fenol ekstrak jahe kering dalam pelarut metanol dan etanol

\begin{tabular}{ccc}
\hline \hline Komponen yang dianalisis & \multicolumn{2}{c}{ Jenis pelarut } \\
& Metanol & Etanol \\
\hline \hline Kadar oleoresin $(\%)$ & $6,38^{\mathrm{a}}$ & $4,10^{\mathrm{a}}$ \\
Kadar fenol $(\mathrm{mg} / \mathrm{ml})$ & $647,22^{\mathrm{p}}$ & $522,22^{\mathrm{q}}$ \\
\hline \hline
\end{tabular}

Keterangan : Superskrip yang berbeda pada baris yang sama menunjukkan perbedaan yang nyata $(\mathrm{P}<0.05)$

Jenis pelarut berpengaruh nyata $(\mathrm{P}<0.05)$ terhadap kadar fenol yang dihasilkan oleh ekstrak jahe. Pelarut metanol menghasilkan total fenol lebih besar. Hasil ini menunjukkan bahwa pelarut metanol mempunyai kelebihan dalam melarutkan komponen fenol yang sangat menentukan daya antioksidatif oleoresin jahe.

Berdasarkan hasil ekstraksi tersebut maka untuk pengujian aktivitas antioksidan oleoresin jahe, karakterisasi dan pengujian pada hewan percobaan selanjutnya, digunakan oleoresin jahe yang di ekstrak dengan pelarut metanol.

\section{Aktivitas antioksidatif oleoresin jahe}

Penghitungan aktivitas antioksidan dilakukan berdasarkan kemampuannya dalam menghambat oksidasi asam linoleat untuk menghasilkan radikal peroksida yang dapat mengoksidasi $\mathrm{Fe}^{2+}$ menjadi $\mathrm{Fe}^{3+}$ dan menghasilkan warna merah. Dengan adanya antioksidan, maka intensitas warna merah yang terbentuk semakin rendah sehingga nilai absorbansi yang terbaca juga semakin kecil. Hasil pengukuran aktivitas antioksidan menunjukkan bahwa oleoresin jahe memiliki aktivitas antioksidan lebih baik dari $\alpha$ tokoferol dan kontrol (Gambar 1).

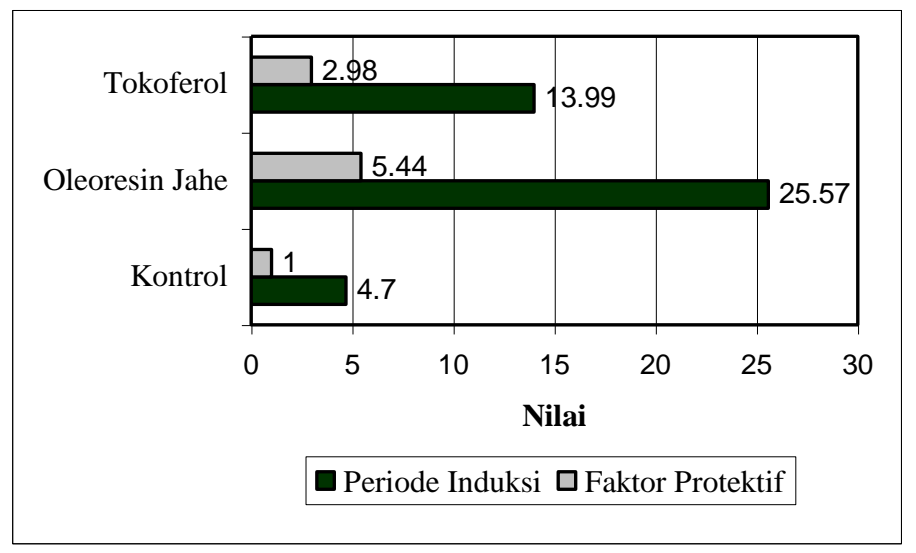

Gambar 1. Nilai periode induksi dan faktor protektif antioksidan oleoresin jahe paling tinggi dibandingkan dengan $\alpha-$ tokoferol dan kontrol. 


\section{Karakterisasi oleoresin jahe}

Karakterisasi oleoresin dengan menggunakan metode Kromatografi Lapis Tipis (KLT) menunjukkan adanya tiga fraksi dengan spot yang cukup tajam dengan nilai $\mathrm{Rf}$ fraksi pertama 0,24, fraksi kedua 0,32 dan fraksi ketiga 0,38. Berdasarkan nilai $\mathrm{Rf}$ pembanding menurut Chen et al. (1996), maka diketahui bahwa fraksi pertama adalah senyawa gingerol, fraksi kedua adalah zingeron dan fraksi ketiga adalah shogaol (Gambar 2).
Analisis KLT tersebut menunjukkan bahwa jahe yang digunakan dalam penelitian ini mengandung komponen aktif antioksidan yaitu gingerol, zingeron, dan shogaol. Pada penelitian ini, pemberian oleoresin jahe pada tikus perlakuan digunakan oleoresin jahe secara keseluruhan (bukan fraksi aktif berdasarkan analisis KLT). Telah dilaporkan bahwa secara in vitro daya antioksidatif oleoresin secara keseluruhan lebih tinggi dibandingan daya antioksidatif masing-masing senyawa fenol penyusunnya.

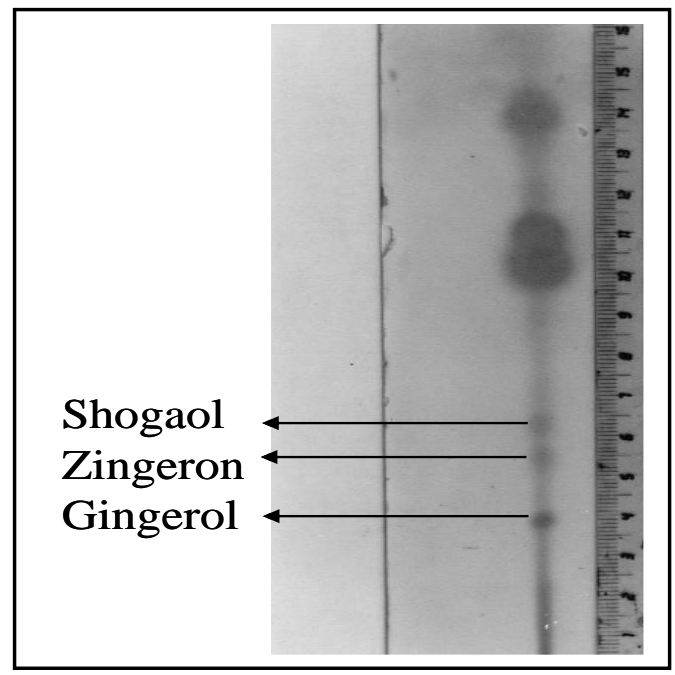

Gambar 2. Kromatogram hasil fraksinasi komponen non volatil oleoresin jahe dengan metode KLT

\section{Kadar MDA hati tikus perlakuan}

Analisis kadar radikal bebas dalam penelitian ini dilakukan dengan mengukur kadar MDA hati tikus perlakuan, karena MDA merupakan indikator keberadaan radikal bebas dalam tubuh. MDA merupakan salah satu produk final dari peroksidasi lipid yang terbentuk setelah aksi senyawa radikal. MDA dalam material biologi telah digunakan secara luas sebagai indikator kerusakan oksidatif, terutama dari asam lemak tak jenuh (Nabet, 1996).

Hasil analisis kadar MDA hati dari keempat perlakuan menunjukkan kadar MDA kelompok stres paling tinggi $(2522,39 \mu \mathrm{mol} / \mathrm{g}$ protein) dibandingkan dengan kadar MDA dari kelompok perlakuan lainnya (Gambar 3). Tingginya kadar MDA tersebut menunjukkan adanya produksi radikal bebas yang meningkat pada kondisi stres.

Pada kondisi puasa, $\beta$ oksidasi dan cytochrome P-450 oxidase meningkat (Ishii et al., 1980; Orellana et al., 1992). Aktivitas oksidasi tersebut menghasilkan radikal bebas sebagai produk samping reaksi tersebut. Tingginya aktivitas oksidasi ini, pada kondisi puasa, menyebabkan produksi radikal bebas seperti anion superoksida $\left(\mathrm{O}_{2}^{-}\right)$juga tinggi. Molekul radikal anion superoksida mengalami dismutasi oleh SOD menjadi singlet oksigen yang dapat menyerang asam lemak tak jenuh (ALTJ) membentuk lipid hidroperoksida dan radikal bebas lipid yang dapat menyebabkan kerusakan membran sel dengan ditandai terbentuknya MDA. Dari mekanisme tersebut terlihat bahwa meningkatnya kadar MDA pada kondisi stres disebabkan karena tingginya 
radikal bebas yang terbentuk, yang akan menghasilkan produk akhir MDA tersebut.

Pemberian oleoresin jahe secara oral pada tikus yang diberi perlakuan stres puasa dan perenangan terjadi penurunan kadar MDA secara nyata. Pemberian oleoresin jahe secara kuratif pada hati menurunkan kadar MDA sebesar $53,57 \%$, sedangkan secara preventif menurunkan kadar MDA sebesar 36,08\%. Persen penurunan MDA pada hati tikus dengan pemberian oleoresin secara kuratif $(\mathrm{S}+\mathrm{O})$ lebih besar daripada tikus yang diberi oleoresin jahe secara preventif $(\mathrm{O}+\mathrm{S})$. Namun demikian, kadar MDA pada hati tikus yang diberi oleoresin baik sebelum dan sesudah stres tidak berbeda nyata $(\mathrm{P}<0.05)$ (Gambar 3$)$. Hal ini menunjukkan bahwa pemberian oleoresin jahe dapat dilakukan baik secara kuratif maupun secara preventif.

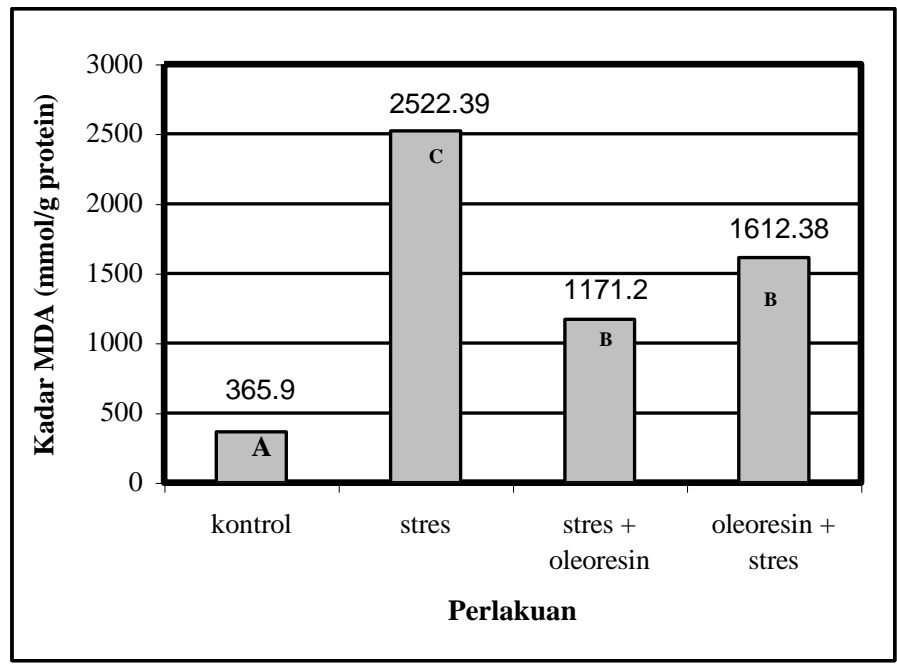

Gambar 3. Perbandingan kadar MDA hati tikus antar perlakuan. (Huruf-huruf yang sama yang mengikuti nilai kadar MDA menunjukkan tidak ada berbedaan yang nyata, $\mathrm{P}>0.05$ ).

Dari hasil analisis ragam menunjukkan bahwa perlakuan stres (puasa dan perenangan) dan pemberian oleoresin $(\mathrm{S}+\mathrm{O})$ berpengaruh nyata $(\mathrm{P}<0.05)$ terhadap kadar MDA hati tikus perlakuan. Berdasarkan hasil uji beda Duncan menunjukkan pada organ hati kelompok kontrol dan kelompok pemberian oloeresin berbeda nyata, sedangkan kadar MDA pada kelompok stres juga berbeda nyata dengan kelompok pemberian oleoresin. Stres yang diberikan ternyata dapat meningkatkan kadar MDA dengan meningkatnya produksi radikal bebas. Pemberian oleoresin jahe memperlihatkan pengaruh yang sangat nyata terhadap kadar MDA, hal ini disebabkan efek antioksidasi dari oleoresin jahe terhadap hati tikus perlakuan cukup besar untuk mengimbangi peningkatan produksi radikal bebas.
Penurunan kadar MDA hati akibat pemberian oleoresin jahe terjadi karena di dalam jahe terdapat senyawa-senyawa fenolik yang mempunyai aktivitas sebagai antioksidan primer (Nienaber et al., 1997), dengan kemampuan tersebut maka proses peroksidasi lipid dan proses lain yang menghasilkan MDA dapat dikurangi.

\section{Aktivitas SOD Hati Tikus Perlakuan}

Analisis kandungan SOD menggunakan spektrofotometer menunjukkan kelompok kontrol mempunyai kandungan SOD tertinggi yaitu $4280 \mathrm{U} / \mathrm{g}$ berat basah (bb) dan terendah dimiliki oleh kelompok stres yaitu $750 \mathrm{U} / \mathrm{g}$ bb (Gambar 4). Pemberian oleoresin jahe pada tikus yang mengalami stres ternyata dapat meningkatkan kandungan SOD dalam hati dibandingkan dengan kelompok tikus yang 
tidak diberi oleoresin. Peningkatan tertinggi ditunjukkan oleh kelompok tikus yang diberi oleoresin sebelum dan sesudah stres berlangsung yaitu sebesar $4040 \mathrm{U} / \mathrm{g}$ bb. Diikuti oleh kelompok tikus yang diberi oleoresin secara kuratif sebesar $3520 \mathrm{U} / \mathrm{g}$ bb dan peningkatan SOD terendah dimiliki oleh kelompok tikus yang diberi oleoresin secara preventif sebesar $2770 \mathrm{U} / \mathrm{g}$ bb.

Analisis sidik ragam menunjukkan bahwa perlakuan stres dan pemberian oleoresin berpengaruh nyata $(\mathrm{P}<0.05)$ terhadap aktivitas SOD hati tikus perlakuan. Uji selanjutnya dengan Duncan's Multiple Range Test (DMRT) menunjukkan bahwa kelompok stres berbeda nyata dengan kelompok lainnya. Antar kelompok $\mathrm{O}+\mathrm{S}+\mathrm{O}, \mathrm{S}+\mathrm{O}$ dan $\mathrm{O}+\mathrm{S}$ tidak ada perbedaan yang nyata, namun kelompok $\mathrm{O}+\mathrm{S}+\mathrm{O}$ dan kelompok $\mathrm{S}+\mathrm{O}$ berbeda nyata terhadap kelompok kontrol (Gambar 4).

Berdasarkan hasil penelitian ini ternyata konsumsi oleoresin jahe dapat meningkatkan kandungan SOD dalam hati tikus pada kondisi stres. Hal ini dikarenakan komponen dalam jahe mempunyai sifat sebagai antioksidan. Berarti komponen jahe yang bersifat antioksidan dapat diserap oleh tubuh sampai ke hati. Berdasarkan hasil penelitian Desminarti (2001) dilaporkan bahwa komponen fenol dapat diserap dan diretensi oleh tubuh dengan dengan daya serap berkisar antara $88 \%$ sampai dengan $95 \%$ dan retensi sebesar $62 \%$ sampai dengan $95 \%$.

Peningkatan aktivitas SOD pada kelompok yang diberi oleoresin jahe menunjukkan komponen oleoresin jahe dapat membantu antioksidan endogen-SOD dalam menetralisir radikal anion superoksida, yang jumlahnya meningkat dalam kondisi stres. Sehingga pemberian oleoresin jahe dapat mencegah penurunan aktivitas SOD pada hati tikus akibat kondisi stres dan hal ini sesuai dengan teori reaksi penetralan anion superoksida oleh enzim SOD maupun oleh komponen oleoresin jahe.

\section{Kandungan Cu,Zn-SOD Hati Tikus Perlakuan secara imunohistokimia}

Kandungan antioksidan intrasel-Cu, ZnSOD yang dideteksi secara imunohistokimia pada hati tikus perlakuan ditunjukkan dengan produk reaksi antigen-antibodi yang berwarna cokelat (Gambar 5). Kandungan $\mathrm{Cu}, \mathrm{Zn}-\mathrm{SOD}$ terlihat paling tinggi pada kelompok kontrol dibandingkan dengan kelompok lainnya, sedangkan kandungan $\mathrm{Cu}, \mathrm{Zn}$-SOD yang paling rendah terlihat pada kelompok stres. Pada kelompok $\mathrm{S}+\mathrm{O}$ terlihat kandungan $\mathrm{Cu}, \mathrm{Zn}$ SODnya lebih tinggi dibandingkan pada kelompok stres.

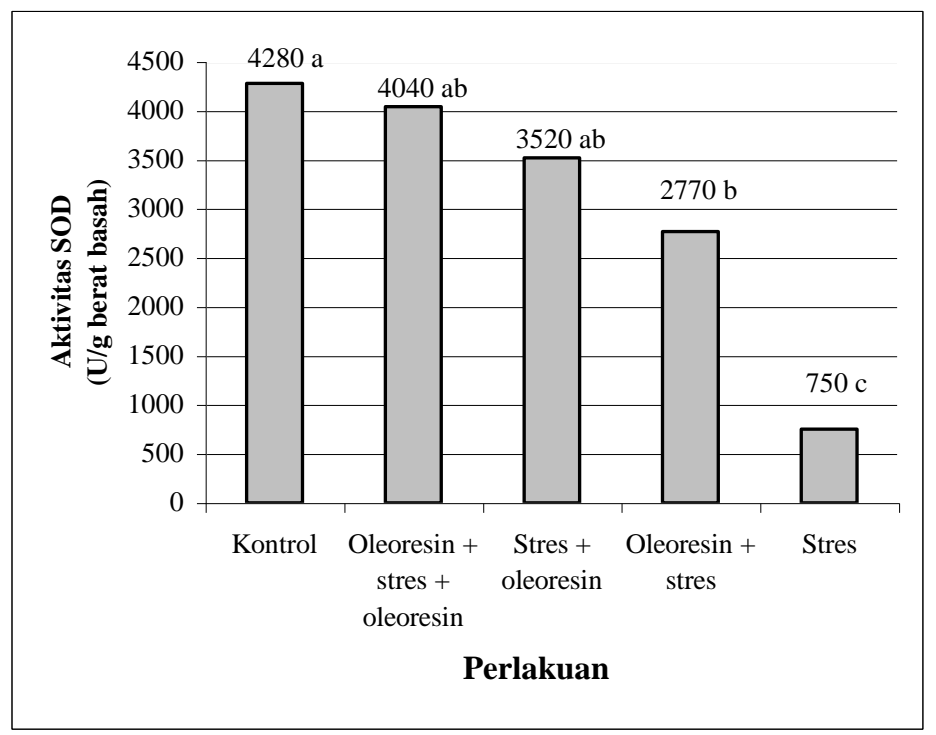

Gambar 4. Aktivitas SOD hati tikus yang mengalami perlakuan stress dan pemberian oleoresin 
Hasil analisis kandungan $\mathrm{Cu}, \mathrm{Zn}-\mathrm{SOD}$ secara kualitatif ini selaras dengan hasil analisis kuantitatif aktivitas SOD dengan spektofotometer. Hasil analisis kandungan $\mathrm{Cu}, \mathrm{Zn}$-SOD tersebut juga mendukung hasil analisis kadar MDA jaringan hati tikus perlakuan. Pada hati kelompok kontrol menunjukkan kadar MDA paling rendah serta kandungan SOD paling tinggi. Sebaliknya pada kelompok stres menunjukkan kadar MDA paling tinggi dan kandungan SOD paling rendah. Pada kelompok perlakuan stres dan oleoresin kadar MDA nya lebih rendah, dan kandungan SOD nya lebih tinggi dari pada kelompok stres. Hal ini menujukkan korelasi antara kadar MDA dengan kandungan SOD. Semakin tinggi kadar MDA maka semakin rendah kandungan SODnya. Sebagai konsekuensi untuk memerangi radikal bebas yang jumlahnya banyak maka diperlukan lebih banyak SOD tubuh untuk mengkatalisnya, sehingga pada kondisi jumlah radikal bebas banyak, yang ditunjukkan dengan tingginya MDA, maka kandungan SODnya menurun.

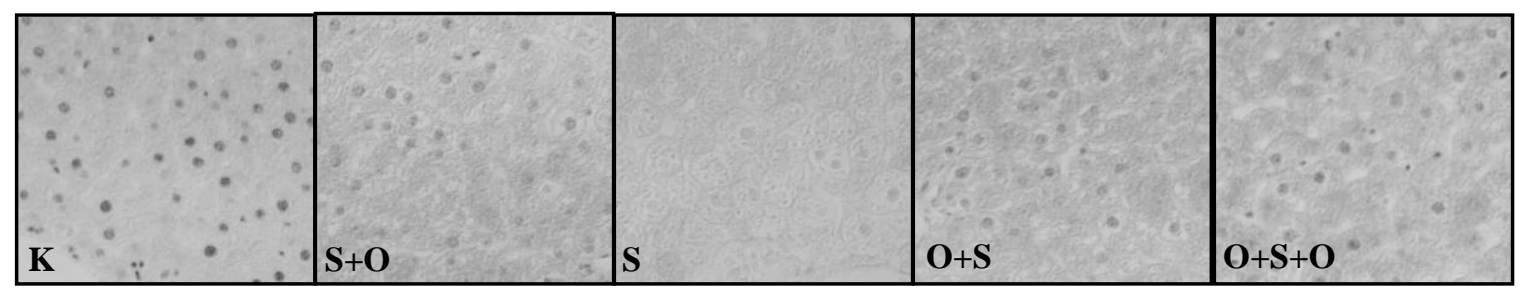

Gambar 5. Gambaran imunohistokimia hati tikus perlakuan terhadap $\mathrm{Cu}, \mathrm{Zn}$-SOD. Kandungan SOD tertinggi terlihat pada kelompok kontrol (K), sedangkan kandungan terendah terlihat pada kelompok stres (S). Pemberian oleoresin menunjukkan adanya peningkatan kandungan SOD dibandingkan kelompok stres. $\mathrm{S}+\mathrm{O}=$ strestoleoresin, $\mathrm{O}+\mathrm{S}=$ oleoresin + stres, $\mathrm{O}+\mathrm{S}+\mathrm{O}=$ oleoresin+stres+oleoresin.

Perlakuan oleoresin pada kelompok stres ternyata memberikan efek yang positif terhadap aktivitas SOD dan kadar MDA. Hal ini menunjukkan bahwa oleoresin jahe mampu mengatasi kelainan atau penurunan SOD jaringan hati tikus akibat stres. Hal ini menunjukkan bahwa perlakuan oleoresin dapat dilakukan baik secara preventif, kuratif, atau kombinasi keduanya. Namun demikian, perlakuan oleoresin jahe secara kombinasi menunjukkan hasil yang paling baik.

\section{Kesimpulan}

Pada kondisi stres kadar MDA hati tikus meningkat, sedangkan aktivitas SOD dan kandungan $\mathrm{Cu}, \mathrm{Zn}-\mathrm{SOD}$ menurun secara nyata. Pemberian oleoresin jahe menurunkan kadar MDA serta meningkatkan aktivitas SOD dan kandungan $\mathrm{Cu}, \mathrm{Zn}-\mathrm{SOD}$ hati tikus secara nyata. Komponen oleoresin jahe mampu bekerja secara sinergis bersama enzim SOD dalam menetralisir radikal bebas endogen, sehingga oleoresin jahe dapat mengatasi kelainan antioksidan intrasel SOD pada jaringan hati tikus di bawah kondisi stres.

\section{Ucapan Terima Kasih}

Penelitian ini merupakan bagian dari Penelitian Hibah Bersaing $X$ yang didanai oleh Proyek Pengkajian dan Penelitian Ilmu Pengetahuan Terapan dari Direktorat Pembinaan Penelitian dan Pengabdian Pada Masyarakat, Direktorat Jendral Pendidikan Tinggi, Departemen Pendidikan Nasional No. 103/LII/BPPK-SDM/IV/2002 untuk TW.

\section{Daftar Pustaka}

AOAC. 1984. Official Methodes of Analysis of the Assosiation of Official Agricultural Chemist. AOAC Inc., Washington.

Asayama, K., Dobashi, K., Kawada, Y., Nakane, T., Kawaoi, A. and Nakazawa, S. 1996. Immunohistochemical localization and quantitative analysis of cellular glutathione peroxidase in fetal and neonatal rat tissues: fluorescence microscopy image analysis. Histochem. J. 28(1):63-71. 
Chen, H.M., Muramoto, K. and Yamauchi, F. 1996. Structural Analysis of Antioxidative Peptides from Soybean $\beta$-Conglicinin. J. Agria. Food Chem. 43:574-578.

Conti, M., Moramd, P.C., Levillain, P. dan Lemonnier, A. 1991. Improve Flurometric Determination of Malonaldehyde. J. Clin. Chem. 37(7):12731275.

Desminarti, S. 2001. Kajian Serat Pangan dan Antioksidan Alami Beberapa Jenis Sayuran serta Daya serap dan Retensi Antioksidan Pada Tikus Percobaan. Tesis (S2). Institut Pertanian Bogor, Bogor.

Dobashi, K., Asayama, K., Kato, K., Kobayashi, M. and Kawaoi, A. 1989. Immuhistochemical localization and quantitative analysis of superoxide dismutase in rat tissue. Acta Histochem. Cytochem. 22:351-365.

Fridovich, I. 1975. Superoxide dismutases. Ann. Rev. Biochem. 44:147-159.

Ishii, H., Horie, S. and Suga, T. 1980. Physiological role of peroxisomal $\beta$-oxidation in the liver of fasted rats. J Biochem. 87 : 1855-1858

Keller, G.A., Warner, T.G., Steimer, K.S. and Halliwell, R.A. 1991. $\mathrm{Cu}, \mathrm{Zn}$-superoxide dismutase is a peroxisomal enzyme in human fibroblasts and hepatoma cells. Proc. Natl. Acad. Sci. USA. 88:7381-7385.

Kikuzaki, H. and Nakatani. N. 1993. Antioxidant effect of some ginger constituents. J. Food Sci. 58:1407-1410.

Marklund, S.L. 1984. Extracellular superoxide dismutase and other superoxide dismutase isoenzymes in tissues from nine mammalian species. Biochem. J. 222:649-655.

Mates, J.M., Gomez, C.P. and Castro, I.N. 1999. Antioxidant enzymes and human diseases. Clin. Biochem. 32(8):595-603.

Nabet, F.B. 1996. Zat gizi antioksidan penangkal senyawa radikal pangan dalam sistem biologis. Di dalam : Prosiding Seminar Senyawa Radikal dan Sistem Pangan : Reaksi Biomolekuler, Dampak Terhadap Kesehatan dan Penangkalan. Kerjasama Pusat Studi Pangan dan Gizi IPB dengan Kedutaan Perancis, Jakarta. Zakaria et. al. (eds). April 4, 1996.

Nienaber, N.L.P., Rahayu, W.P. dan Andarwulan, N. 1997. Sifat Antioksidan dan Antimikroba Rempah-Rempah dan Bumbu Tradisional. Di dalam: Prosiding Seminar Sehari Khasiat dan Keamanan Rempah, Bumbu dan Jamu Tradisional, PAU Pangan dan Gizi, IPB, Bogor. 8 Maret.
Orellana, M., Fuentes, O., Rosenbluth, H., Lara, M. and Valdes F. 1992. Modulatios of rats liver peroxisomal and microsomal fatty acids oxidation by starvation. FEBS 310: 193-196.

Schuler, P. 1990. Natural antioxidants exploited commercially. pp.99-170. In : Food Antioxidants (Hudson, B. J. F. ed.), Elsevier Applied Science, London.

Touati, D. 1992. Regulation and protective role of the microbial superoxide dismutases. Pp231-261. In: Molecular Biology of Free Radical Scavenging Systems (Scandalios. ed.), Cold Spring Harbor Laboratory, New York

Wresdiyati, T. and Makita, T. 1995. Remarkable increase of peroxisomes in the renal tubule cells of Japanese monkeys under fasting stress. Pathophysiology 2: 177-182.

Wresdiyati, T and Makita, T. 1997. Immunocytochemical localization of $\mathrm{Cu}, \mathrm{Zn}$-SOD (Cooper, zincsuperoxide dismutase) in the renal tubules and glomerulus of rat kidney. Mol. Biol.Cell. 8:342.

Wresdiyati, T. 1999. Immunocytochemical of Localization oxygen Free Scavenger Copper, Zinc Superoxide Dismutase (Cu,Zn-SOD) in Rat Kidney. Gakuryoku. 5(1):1-7.

Wresdiyati, T., Mamba, K., Adnyane, I.K.M. and Aisyah, U.S. 2002. The effect of stress condition on the intracellular antioxidant copper, zincsuperoxide dismutase $(\mathrm{Cu}, \mathrm{Zn}-\mathrm{SOD})$ in the rat kidney : an immunohistochemical study. Hayati. 9(3):85-88.

Wresdiyati, T., Lelana, R.P.A., Adnyane, I.K.M. dan Noor, K. 2003. Immunohistochemical study of superoxide dismutase (SOD) in the liver of diabetic experiment Macaca fascicularis. Hayati. 10(2):61-65

Wresdiyati, T. 2003a. Immunohistochemical study of oxygen-free radical scavenger superoxide dismutase $(\mathrm{Cu}, \mathrm{Zn}-\mathrm{SOD})$ in the liver of rats under stress condition. Biota. VIII(3):107-112

Wresdiyati, T. 2003b. Pemanfaatan ekstrak jahe (Zingiber officinale) sebagai antiinflamasi pada jaringan hati tikus di bawah kondidi stres. Jurnal Veteriner.4(4):154-163

Wresdiyati, T., Astawan, M. dan Adnyane, I.K.M. 2003. Aktivitas anti inflamasi ekstrak jahe (Zingiber officinale) pada ginjal tikus akibat stress. Jurnal Teknologi dan Industri Pangan. XIV(2):113-120 